\title{
Social Justice, Children's Needs and Rights: An Approach to Planning
}

\author{
Margaret Sims ${ }^{1, *}$ \\ ${ }^{1}$ School of Education, University of New England, Armidale, NSW, Australia \\ *Correspondence: University of New England, Elm Avenue, Armidale, NSW 2351, Australia. Tel: 61-2-6773-3823. \\ E-mail: margaret.sims@une.edu.au
}

Received: October 19, 2015 Accepted: November 10, $2015 \quad$ Online Published: November 15, 2015

doi:10.5430/jct.v4n2p122 URL: http://dx.doi.org/10.5430/jct.v4n2p122

\begin{abstract}
Commonly, planning for children involves comparing what they know against a curriculum or learning framework which identifies what they should know. Early childhood educators are then expected to create learning opportunities to help fill the gap between these two extremes. In this paper I argue that such an approach does not honour the requirements outlined in the United Nations Convention on the Rights of the Child, particularly in relation to respecting children's agency. Rather, in this approach adults possess and enact power over children: adults make the decisions about what children should know and what and how they will be taught. I propose an alternative framing of planning. The focus of the planning becomes what early childhood educators need to do to ensure children's rights are met rather than on what children need to learn to meet the requirements of the relevant curriculum or learning framework.
\end{abstract}

Keywords: children's rights; programme planning; United Nations Convention on the Rights of the Child

\section{Introduction}

For many years early childhood practitioners have been guided by the ideas of developmentally appropriate practice (DAP - Bredekamp, 1986; National Association for the Education of Young Children, 2009), a framework aimed at ensuring the highest possible quality practice when working with young children. DAP requires that early childhood educators use their knowledge of theory, child development, curriculum, culture, family and context to identify "what children should know, understand, and be able to do" (National Association for the Education of Young Children, 2009, p. 20); identifying goals for each child "including all those foundational for later learning and school success" (p20). In other words, the focus is on "the knowledge, skills, abilities, and understandings children are to acquire" (p20). In this paper I argue that such a focus encourages early childhood educators to focus on what children do NOT know, in order to plan opportunities for children to learn these identified gaps in their knowledge and understanding. This is a deficit focus and it positions children as recipients of their teachers' agency, rather than as agentic beings in their own right. I propose an alternative approach to planning which focuses on children's rights, and positions then as active agents in their own learning.

\section{Deficit Planning}

Deficit planning could be seen to arise from the medical model where, as Shah and Mountain (2007) point out, the focus is on a problem that can be identified then fixed. Harry and Klingner (2007) discuss the deficit approach in education where it is responsible for the focus on student learning needs (and ultimately student learning challenges). Focusing on learning needs identifies the knowledge or skills that children do not have. The assumption is that they need to learn these identified pieces of knowledge and/or skills and will benefit from doing so. Power in this context is held in the hands of the early childhood educator. The educator (guided perhaps by knowledge of child development and curriculum requirements) decides that the child needs this particular piece of knowledge and/or skill, and plans the opportunities to be offered in order for the child to learn them. The language used usually involves terms such as 'learning goals' or 'learning outcomes'. Whatever terms are used, the focus is on what the child does not know yet and what someone (the early childhood educator) has determined the child should know or do. There is no opportunity for child agency in the determination of these learning goals. Whilst it is strongly recommended that early childhood educators consult with, and work with parents in order to choose relevant learning 
goals (for example the Australian Early Years Learning Framework emphasises the importance of partnerships with parents - Department of Education Employment and Workplace Relations, 2009), young children are not included in this decision making despite the fact that the decisions made will impact on their day-to-day experiences in the early childhood programme.

There is considerable research now that identifies the risks associated with deficit planning. The focus on problems is found to create a sense of helplessness in clients and a dependency on external support when used in community work contexts (Centre for Child Wellbeing, 2011). This characteristic outcome was identified over 40 years ago as learned helplessness (Maier \& Seligman, 1976) and researchers continue to identify learned helplessness as a key concern in limiting student performance (Jose \& Bellamy, 2012; Mikulincer, 1994). In a similar manner, a lack of cultural capital (cultural capital as identified by Bourdieu, 1991) is often positioned as the underlying cause of lower academic achievement levels of young children from minority cultural backgrounds or from disadvantaged backgrounds. This deficit is seen as a problem belonging to the individual child and family and the 'fix' is to ensure, through early childhood education, "children must develop properly according to normalised understandings and that parents must do all that they can to enable this proper development" (Macfarlane \& Lakhani, 2015, p. 185). A deficit approach identifies children and parents who do not fit the norm as problems, as deviants, which in turn denies their agency and their strengths.

The language of needs is deeply entrenched in educational planning. Early childhood educators, when planning for children, use their observations as a basis for identifying what they think children need to learn next (a learning goal or a learning outcome), then devise appropriate learning opportunities. In many contexts these are written into a formal programme which can sometimes be made available to families. In the US Brown (2015, p. 238) reports that the kindergarten teachers in his study were "expected to turn in weekly time sheets that document what they are teaching their students each day and for how long." These reports are used to check that "all the teachers across the district are teaching all of their students the same knowledge and skills through a similar set of practices for an appropriate amount of time to ready them for the state's high-stakes tests that begin in grade 3" (pp 238 - 239). In Australia, the Early Years Learning Framework identifies desired outcomes for children's learning (Department of Education Employment and Workplace Relations, 2009). Educators are required to plan a learning programme for each child, document how children are progressing towards their identified learning outcomes and evaluate children's learning in an ongoing cycle. Whilst the intention is to operate from strengths, the focus on learning needs and desired outcomes encourages deficit thinking (Sims, 2011).

\section{An Alternative - A Rights Focus}

An alternative to planning for children by focusing on needs is an approach that focuses on rights (Sims, 2011). The concept of children's rights came to the fore with the United Nations Declaration on the Rights of the Child (United Nations, 1959) and the later Convention (UNCROC - United Nations, 1989). UNCROC addressed a number of areas, one of which is the concept of the best interests of the child which is often used to justify decisions made by adults for children in Family law in Australia (Kaspiew et al., 2009) despite the requirement in UNCROC for children to be involved in decisions that impact on them. Rights thinking, I argue, whilst it has made some impact in the way we perceive and work with children, has not overturned the deficit thinking that drives much of the planning work undertaken by early childhood educators. Partly this is because the provisions in UNCROC are often perceived as being in conflict with the rights of parents (Freeman, 2014; Richards, 1993-4) and thus a rights approach often generates discomfort in early childhood practitioners and parents. Children are often perceived as "'becomings' rather than as 'beings"' (Freeman, 2014, p. 5). Children who are 'becoming' require an adult to make decisions in their best interests (note that the Australian Early Years Learning Framework uses the word 'becoming' in its title Department of Education Employment and Workplace Relations, 2009) suggesting that, again despite best intentions, deficit thinking is hegemonic and difficult to dislodge. A similar situation is discussed by Macfarlane and Lakhani (2015) in their analysis of the Australian National Early Childhood Strategy: here the argument is that the strength of hegemonic understandings of children, and their positioning as beings who are becoming, leads even the best intentioned into paths that reinforce children's lack of agency and lack of power.

\subsection{Beginning with Strengths}

A rights-based approach to planning, I argue (Sims, 2011) begins with a focus on strengths. A strengths-based approach has been used for many years across a range of education and support services (Sims, 2002). This focus is known to improve wellbeing and help alleviate depression (Gander, Proyer, Ruch, \& Wyss, 2013) and leads to improved outcomes for children in educational settings (Passareilli, Hall, \& Anderson, 2010). Strength-based 
interventions can improve teacher-child interactions and child behavior (Sutherland, Conroy, Abrams, \& Vo, 2010). Strengths are the foundation of the positive psychology movement (Gander et al., 2013; Lopez \& Snyder, 2009; Seligman \& Csikszentmihalyi, 2000) which, when implemented in schools becomes positive education aimed at developing "enabling schools" (White \& Waters, 2015, p. 69).

Table 1. An Introduction to Mere - An Abridged Strengths/Interests Profile

\begin{tabular}{|c|c|}
\hline Strengths & Interests \\
\hline - Walks unsteadily on flat ground & - 3 favourite books - is \\
\hline - Safely negotiates stairs on her bottom & happy to hear these \\
\hline - Sits for approximately 2 minutes on the floor at group time & stories every day \\
\hline - Joins with other children in songs at group time & - 'dancing' to music \\
\hline - Sings favourite songs with some words understandable & - Painting at the easel, \\
\hline - On request will hold out her arms to check spacing between herself and & $\begin{array}{l}\text { can choose to use pink } \\
\text { or purple }\end{array}$ \\
\hline - Attempts to imitate a jump and usually lifts one foot off the ground & - Rolling playdough and \\
\hline - Uses about 25 single words and several two word phrases & - Slices of apple and pear \\
\hline - Follows simple one-step directions & \\
\hline - Hugs other children & \\
\hline - Strong relationship with EC educator Sam & \\
\hline - EC Educator Pep can sometimes comfort her when Sam is not available & \\
\hline - Requests favourite books to be read to her, particularly by Sam & \\
\hline $\begin{array}{l}\text { - Will listen to stories } 1 \text {-on-1 for } 10 \text { minutes, especially if some of her } \\
\text { favourite stories are included }\end{array}$ & \\
\hline - Points to several pictures in favourite books & \\
\hline - Finger feeds & \\
\hline - Beginning to feed self with spoon & \\
\hline - Beginning to show awareness when nappies are wet or soiled & \\
\hline - $\mathrm{Ma}$ & \\
\hline Holds pencil in tripod grip & \\
\hline
\end{tabular}

A focus on strengths links into Vygotsky's concept of the Zone of Proximal Development (Vygotsky, 1962). As in Vygotsky's theory, our planning starts with a clear understanding of what children already know and do. This is done through observation of children engaging in their natural and normal environments. We observe children doing what they normally do on a regular, ordinary day in the regular, ordinary settings in which they participate. Different methods of recording our observations abound (Blaiklock, 2010; Dockett, 2011; Flannery Quinn \& Manning, 2013; Hallam, Lyons, Pretti-Frontczak, \& Grisham-Brown, 2014; Sims, 2011) but the key here is to ensure that we document children's strengths. I suggest (Sims, 2011) that we then need to create a summary of our observations which we can do in a strengths/interests profile (see Table 1).

\subsection{Moving on to Children's Rights}

Once we have a clear idea of children's strengths it is time to frame our planning in terms of children's rights. I have amended Maslow's Hierarchy of Needs (Maslow, 1970) into a Framework of Rights (see Figure 1). 
Figure 1. Maslow's Hierarchy of Needs Reframed as a Hierarchy of Rights

This framework allows early childhood educators to reframe their thinking to focus on rights. The question to ask at each level of the hieracrchy is: how are this child's rights being met at the moment? Our knowledge of the child and family (obtained through discussions in the context of a trusting parent-educator partnership), our knowledge of the community and context and our observations of the child all feed into the information presented in the Rights Framework. The important element here is that the focus is on what early childhood educators do to ensure children's rights are met, NOT on what children need to learn. This is demonstrated in Table 2. Note that children's rights can be met in a variety of different ways: there is no ONE right way. It is here that we are able to take into account cultural, familial and contextual diversity. For example a young Asian child may have his rights for nutrition met by his older brother who feeds him. In a western early childhood setting where independence in feeding is usually considered a desirable outcome, educators may initially decide that it is important for the child to be able to feed himself independently. However, a focus on rights prompts reflection: is the child's right to nutrition being met? If so, are the family satisfied with the manner in which this right is being met? Are we able to meet the child's rights in our service in this way? If older brother also attends the service can he continue in this role (meeting his own rights for feeling valued)? It may be that, in consultation with the family, a decision is made that the way in which the child's rights to nutrition are being met at the moment is fine. Alternatively, the family may agree that in the early childhood setting it would be useful for the child to be able to meet his rights for nutrition independently, without in any way, interfering with how the right to nutrition is met at home.

\subsection{Planning from the Rights Framework}

Once we have identified what it early childhood educators are aiming to achieve to ensure children's rights are met it is time to move on in the planning to organize what it is they actually have to do. Here, in the past we have developed goals and objectives for each child. In this planning framework we rather develop goals and objectives for early childhood educators: and given the implicit meanings that are associated with the words 'goal' and 'objective' I have chosen to use substitute terms. A 'Recommendation for Planning' offers the longer term outcome that addresses a way in which a child's right can be met. This should be broken down into smaller steps, achievable in the short 
term, and focused on 'our actions': what early childhood educators have to do. This is illustrated in Table 3.

Once we have determined what we are doing, we then identify the specific details of how we will do it. This is the level of planning that may change from day to day to week to week as we offer learning opportunities and reflect on the child's participation. Here is where we refer to key principles in planning (Sims, 2011):

1. Understanding children's interests will help us plan learning opportunities in which children will choose to participate. We do not force children to participate in learning opportunities; rather we create opportunities using our knowledge of children's interests and make ourselves available to scaffold and support their participation when they choose to engage,

2. Given that routines (eating, toileting, dressing, washing etc) take up a lot of time throughout the day, we have to find ways to use them to create learning opportunities,

3. The ways in which we interact with children and scaffold their engagement in an activity, makes the difference between learning or not learning, and shapes what children learn when engaging in an activity or routine.

\section{Evaluation}

Every time a child engages in an activity or a routine we have identified as a relevant learning opportunity we observe. This enables us to determine if that planned opportunity worked the way we thought it might, and that the child did learn from participating. We observe to determine if we should repeat that same opportunity or need to change to something else. An accumulation of observations will help us understand if the Recommendation for Planning that we are working on remains relevant or should be amended. We can go back to our Rights Framework and determine if there are now other priorities we should be addressing.

Table 2. A Rights Framework for Mere

Level
$\begin{aligned} & \text { How the child's rights are currently } \\ & \text { being met }\end{aligned}$ $\begin{aligned} & \begin{array}{l}\text { What early childhood educators } \\ \text { have to do to ensure rights are met } \\ \text { (from observations and discussions } \\ \text { with parents and others) }\end{array} \\ & \begin{array}{l}\text { 1: rights to food, shelter, Mere feeds herself with finger } \\ \text { warmth etc } \\ \text { foods }\end{array} \\ & \begin{array}{l}\text { Need to be nearby when she is a spoon as she requires } \\ \text { support to eat sufficient food }\end{array}\end{aligned}$

2: the right to physical Mere negotiates the physical Need to ensure obstacles in her safety - avoiding external environment with some risk at this walking path are avoidable dangers and things that point might harm: safety, security and protection;

Need to ensure that changes in levels (eg stairs) are clearly identified in time for her to move to her bottom

3: the right to love, Mere has a strong relationship with Build a stronger relationship with affection, care, attention, Sam

closeness to another person; Pep so that Mere is not completely dependent on Sam to feel safe in the EC environment

4: the right to feel valued Mere copies other children at group Be available to help her find safe and worthy, to be valued by time and in other group activities spacing between her and other others, to be accepted, which helps her feel part of the children before 'dancing' or playing appreciated and have status; group active games such as "Simon Says"

5: the right to realise one's Mere is using a range of words, and Make sure she has exposure to potential. Maslow calls this is beginning to point to objects in interesting books and objects to self-actualisation. books increase her vocabulary 


\section{Conclusion}

For too long our work with young children has taken a deficit approach. This approach positions the child as the recipient of adult actions, and national curricula which "inform all stakeholders about what children should be learning and doing each stop of the way in their early education systems" (Brown, 2015, p. 237) have not helped despite their espoused aim of viewing children as active agents in their own learning. I believe it is important that we made a radical shift in the way in which we think about planning learning experiences for children so that we enact in our words and our deeds, the principles outlined in UNCROC. I argue that we need to take a rights focus, and move the emphasis away from what we think children ought to learn to what we, as early childhood educators, must take responsibility for doing to ensure children's rights are met. When we do this, then we make positive steps towards truly making UNCROC a living document.

Table 3. Planning for Mere

Recommendation for Planning: for early childhood educators to provide opportunities for Mere to increase her control over walking

\begin{tabular}{ll}
\hline Our Actions & Strategies \\
\hline $\begin{array}{l}\text { To provide Mere with } \\
\text { opportunities }\end{array}$ to & $\begin{array}{l}\text { Play "Simon Says" every day this week and include several opportunities to (a) crouch } \\
\text { down then spring up again and (b) lie on the back doing bicycle movements } \\
\text { strengthen leg muscles } \\
\text { Make sure dancing music is played every day. Provide scarves and offer actions the } \\
\text { children can imitate (a) jumping up and down with the scarves (b) lie on back with legs } \\
\text { in the air and the scarf clasped between the feet then wave the scarf back and forth, up } \\
\text { and down } \\
\text { Provide the ride on bikes outside (note she particularly likes the 'shoe' shaped one) and } \\
\text { be available to give her a few pushes when she gets on, watch if she gets stuck and be } \\
\text { available to provide a little assistance }\end{array}$ \\
$\begin{array}{l}\text { Make sure dancing music is played every day as above. Provide scarves and offer actions } \\
\text { topportunities }\end{array}$ & $\begin{array}{l}\text { the children can imitate (a) move from one leg to the other whilst waving the scarf (b) } \\
\text { momentarily stand on one leg whilst waving scarf }\end{array}$ \\
improve balance & $\begin{array}{l}\text { When putting on her pants after a nappy change, have her stand on the floor and hold } \\
\text { adult shoulders (adult crouched down) and balance whilst together you put each leg into } \\
\text { the pants }\end{array}$ \\
& $\begin{array}{l}\text { Put out the small portable slide each day this week. Be available to support her in } \\
\text { climbing up the 3 steps so that she transfers weight from one leg to the other as she } \\
\text { climbs }\end{array}$ \\
\hline
\end{tabular}

Recommendation for Planning: for early childhood educators to provide opportunities for Mere to build a secure and trusting relationship with Pep

\begin{tabular}{ll}
\hline Our Actions & Strategies \\
\hline $\begin{array}{l}\text { To provide Mere and } \\
\text { Pep with one-on-one } \\
\text { time together }\end{array}$ & $\begin{array}{l}\text { Make sure that Pep does Mere's nappy changes this week. Pep needs to talk with Mum } \\
\text { first to find out the way Mere particularly likes her nappy changed and what } \\
\text { games/song/activities they share during nappy changes }\end{array}$ \\
& $\begin{array}{l}\text { Make sure that Pep is stationed near Mere at meal times so that she is available to help } \\
\text { scaffold the spoon feeding } \\
\text { Make sure Pep is rostered on early shifts this week so she can be there when Mum comes } \\
\text { in with Mere. Spend 5 minutes at the beginning of the day with Mere to help settle her. }\end{array}$ \\
& $\begin{array}{l}\text { Pep will offer dancing every day this week and encourage Mere to participate by asking } \\
\text { her to choose the first dance music }\end{array}$ \\
$\begin{array}{l}\text { Top provide Mere and } \\
\text { to have a good time } \\
\text { together }\end{array}$ & $\begin{array}{l}\text { During the morning transition into care, Pep will spend 5 minutes reading one of Mere's } \\
\text { favourite stories with her. }\end{array}$ \\
& $\begin{array}{l}\text { Make sure that either pink or purple paint are one of the choices of paint at the easels this } \\
\text { week. Pep to join Mere when she goes to the easel and initiate a conversation related to }\end{array}$ \\
& $\begin{array}{l}\text { Mere's painting. Make sure this is relaxed and encourage Mere to express her feelings in } \\
\text { whatever manner she wishes }\end{array}$ \\
\hline
\end{tabular}




\section{References}

Blaiklock, K. (2010). Assessment in New Zealand early childhood settings. A proposal to change from Learning Stories to Learning Notes. Early Education, 48(2), 5-10.

Bourdieu, P. (1991). Language and symbolic power Cambridge, MA: Harvard University Press.

Bredekamp, S. (Ed.). (1986). Developmentally appropriate practice in early childhood programs serving children from birth through age 8 (expanded edition ed.). Washington: National Association for the Education of Young Children.

Brown, C. P. (2015). Conforming to reform: Teaching pre-kindergarten in a neoliberal early education system. Journal of Early Childhood Research, 13(3), 236-251. http://dx.doi.org/10.1177/1476718x14538602

Centre for Child Wellbeing. (2011). Strengths-Based versus Deficit-Based Approaches. Research Bytes, 2,6 pages downloaded. http://www.mtroyal.ca/cs/groups/public/documents/pdf/strengthsvsdeficitrb.pdf

Department of Education Employment and Workplace Relations. (2009). Belonging, being and becoming. The Early Years Learning Framework for Australia. Canberra, ACT: Commonwealth of Australia.

Dockett, S. (2011). Ethical assessment. Every Child, 17(3), 8.

Flannery Quinn, S., \& Manning, J. (2013). Recognising the Ethical Implications of the Use of Photography in Early Childhood Educational Settings Contemporary Issues in Early Childhood, 14(3), 270 - 278. http://dx.doi.org/10.2304/ciec.2013.14.3.270

Freeman, M. (Ed.). (2014). The future of children's rights. Leiden: Brill Nijhoff.

Gander, F., Proyer, R., Ruch, W., \& Wyss, T. (2013). Strength-Based Positive Interventions: Further Evidence for Their Potential in Enhancing Well-Being and Alleviating Depression.Journal of Happiness Studies, 14(4), 1241-1259. http://dx.doi.org/10.1007/s10902-012-9380-0

Hallam, R. A., Lyons, A. N., Pretti-Frontczak, K., \& Grisham-Brown, J. (2014). Comparing Apples and Oranges: The Mismeasurement of Young Children Through the Mismatch of Assessment Purpose and the Interpretation of Results. Topics in Early Childhood Special Education, 34(2), 106-115. http://dx.doi.org/10.1177/0271121414524283

Harry, B., \& Klingner, J. (2007). Discarding the deficit model. Educational Leadership, 64(5), 16 - 21.

Jose, P. E., \& Bellamy, M. A. (2012). Relationships of Parents' Theories of Intelligence With Children's Persistence/Learned Helplessness: A Cross-Cultural Comparison. Journal of Cross-Cultural Psychology, 43(6), 999-1018. http://dx.doi.org/10.1177/0022022111421633

Kaspiew, R., Gray, M., Weston, R., Moloney, L., Hand, K., Qu, L., \& Family Law Evaluation Team. (2009). Evaluation of the 2006 Family Law Reforms. Melbourne: Australian Institute of Family Studies.

Lopez, S., \& Snyder, C. (2009). The Oxford Handbook of Positive Psychology (2 ed.). New York: Oxford University Press.

Macfarlane, K., \& Lakhani, A. (2015). Performativity, propriety and productivity: The unintended consequences of investing in the Early Years. Contemporary Issues in Early Childhood, 16(2), 179-191. http://dx.doi.org/10.1177/1463949115585441

Maier, S. F., \& Seligman, M. E. (1976). Learned helplessness: Theory and evidence. Journal of Experimental Psychology: General, 105(1), 3-46. http://dx.doi.org/10.1037/0096-3445.105.1.3

Maslow, A. (1970). Motivation and personality. New York: Harper and Row.

Mikulincer, M. (1994). Human Learned Helplessness: A Coping Perspective. New York: Springer Schience+Business Media.

National Association for the Education of Young Children. (2009). Developmentally Appropriate Practice in Early Childhood Programs Serving Children from Birth through Age 8 (pp. 32 pages downloaded). available at https://www.naeyc.org/files/naeyc/file/positions/PSDAP.pdf, downloaded 13 October 2015: National Association for the Education of Young Children.

Passareilli, A., Hall, E., \& Anderson, M. (2010). A strengths-based approach to outdoor and adventure education: possibiities for personal growth. Journal of Experiential Education, 33(2), 120 - 135.

Richards, J. (1993-4). Redefining parenthood: parental rights versus child rights. Wayne Law Review, 40, 1227 - 
1272.

Seligman, M., \& Csikszentmihalyi, M. (2000). Positive Psychology: An Introduction. American Psychologist, 55(1), 5 - 14.

Shah, P., \& Mountain, D. (2007). The medical model is dead - long live the medical model. The British Journal of Psychiatry, 191(5), 375-377. http://dx.doi.org/10.1192/bjp.bp.107.037242

Sims, M. (2002). Designing family support programmes. Building children, family and community resilience. Champaign, Illinois: The Learner.

Sims, M. (2011). Social Inclusion and The Early Years Learning Framework: a way of working. Castle Hill, NSW: Pademelon Press.

Sutherland, K. S., Conroy, M., Abrams, L., \& Vo, A. (2010). Improving Interactions Between Teachers and Young Children with Problem Behavior: A Strengths-Based Approach. Exceptionality, 18(2), 70-81. http://dx.doi.org/10.1080/09362831003673101

United Nations. (1959). Declaration of the Rights of the Child. Proclaimed by General Assembly resolution 1386(XIV) of 20 November 1959. Retrieved $20 \quad$ March, 2001, from http://www.unicef.org/malaysia/1959-Declaration-of-the-Rights-of-the-Child.pdf

United Nations. (1989). Convention on the Rights of the Child with Annex. (A/RES/44/25). Geneva: United Nations Retrieved http://sithi.org/admin/upload/law/Convention\%20on\%20the\%20Rights\%20of\%20the\%20Child.ENG.pdf

Vygotsky, L. (1962). Thought and knowledge (E. V. Hanfmann, G, Trans.). Cambridge, Mass: MIT Press.

White, M. A., \& Waters, L. E. (2015). A case study of 'The Good School:' Examples of the use of Peterson's strengths-based approach with students. The Journal of Positive Psychology, 10(1), 69-76. http://dx.doi.org/10.1080/17439760.2014.920408 